\title{
Global Education: How do we Respond?
}

\author{
Heitor Gurgulino de Souza
}

\begin{abstract}
In this paper, Professor Heitor Gurgulino de Souza, briefly describes the goals that World Academy of Art and Science (WAAS) had stated, 40 years ago, when it was established, and its role as a 'World University'. Then he mentions the United Nations University (UNU), created by UN Secretary General U Thant, with support from UNESCO, when the UN General Assembly adopted the charter of UNU, on December 1973. He briefly describes the organization and first years of activities of the UNU globally, from its center in Tokyo, J apan, since 1975. Why Tokyo? Because, at that time, a very generous offer was made by the government and people of J apan: (1) To donate US $\$ 100$ million to the endowment fund of UNU; (2) to build its permanentheadquarters in Tokyo and (3) to establish a research and training center of the UNU in J apan. He also describes briefly the UNU Research and Training Centers (RTCS) and programs (RTPS), established worldwide. Finally, he mentions another case of a globalization, being implemented by Brazil'S cience without Borders Program' (CSF), during 2011-2015. Goal: to send over 100,000 students abroad (with fully funded fellowships) to study and do research at good universities in other countries and to attract visiting teachers and researchers from abroad to come and work in Brazil.
\end{abstract}

Keywords: University, WAAS, Globalization, Brazil, Internationalization.

How to cite this article: de Souza HG. G lobal E ducation: How do we Respond? Donald School J Ultrasound Obstet Gynecol 2013;7(3):268-271.

\section{Source of support Nil}

\section{Conflict of interest: None declared}

F ifty years ago- the World Academy of Art and Science

Ten years later - the U nited Nations U niversity

Today-Brazil's Higher Education \& Science without borders

First of all I wish to thank the Dubrovnik International University and Ivo Slaus, President, W orld A cademy of A rt and Science (WAAS)-for their kind invitation for me to address this Second Global Congress of the Ian Donald Schools, in Croatia, on the theme of global education. This is certainly very timely for this XXI Century, due to a fast and continuously globalizing world we live in but, in reality, it is not a new idea. 'The great Greek philosopher Plato was the founder of an academy, that carried its work through nine centuries (namely from 387 B C until 529 A D) and had a great 'global' goal, at that time. His main aim was the scientific and philosophical training of potential political leaders. $^{1}$ Centuries later, in December 1960, a highly distinguished group of scholars, scientists and humanists decided to create W A AS, and stated that it ' would function as an informal 'World University' of the highest scientific and ethical level' and one of its aims was: 'To build up a transnational forum in which the vital problems of mankind can be responsibly discussed and thoroughly studied by the best brains of our generation and of the following ones, from an objective, scientific and global point of view.' And WAAS has been doing that, since its founding, through lectures, seminars, conferences, workshops and publications. Now, 50 years later, WAAS is also seriously considering using the new $\mathrm{TIC}^{\prime}$ 's to further broaden its reach, to older and younger generations al ike and to future leaders of our globe, through a 'W orld V irtual U niversity'.

But, as we look at global education today, I respect even more and appreciate the vision of those that, under the leadership of then UN Secretary General U Thant, in the beginning of the 1970s, proposed that the United Nations create a university that, according to its charter: 'shall be an international community of scholars, engaged in research, postgraduate training and dissemination of knowledge in furtherance of the purposes and principles of the charter of the United Nations'. It shall function 'through a central programming and co-ordinating body and a network of research and postgraduate training centers and programs located in developed and developing countries,' therefore UNU should act throughout the world, and it ' should devote its work to research into the pressing global problems of human survival, development and welfare, that are the concern of the $U$ nited Nations and its agencies, with due attention to the social sciences and humanities as well as natural sciences, pure and applied' ${ }^{2}$-charter of the UN University, 1973.

The charter of the UNU, approved by the General A ssembly of the U nited Nations, in December 1973, states that: 'The research programs of the institutions of the university shall include, among other subjects, coexistence between peoples having different cultures, languages and social systems; peaceful relations between States and the maintenance of peace and security; human rights; economic and social change and development; the environment and the proper use of resources; basic scientific research and the application of the results of science and technology in the interests of development and universal human values related to the improvement of the quality of life.' Indeed, UNU has to deal with global issues and values.

By its charter, UNU enjoys academic freedom and autonomy within the framework of the $U$ nited $\mathrm{N}$ ations and all its funds come from voluntary contributions made by 
governments, foundations or by the private sector. It does not receive one single dollar from the annual budget of the U nited Nations!! It has a governing council, composed of 24 members, jointly appointed, in their individual capacity, by the UN Secretary General and the Director General of UNESCO.

Thanks to the very generous offer made by the government and people of J apan, to donate US $\$ 100$ million to the endowment fund of the university; to build a permanent building for the UNU, as well as setup one of its research and training centers in the country, Tokyo has been chosen as the headquarters of UNU.

It started its operations there, initially in temporary facilities, in 1975, after the appointment of the first rector and its initial global co-operative research programs had three priority areas: 'world hunger-food and nutrition', 'natural resources' and 'socioeconomic development'. Work only started on the construction of the permanent headquarters building in 1989, when I was the third rector of UNU and it was completed in 1993. Then, I had the great pleasure and honor to organize its inauguration, in the presence of the Crown Prince of J apan, the UN Secretary General (B outros Boutros-Ghali), the Director General of UNESCO (Federico Mayor), the M inistries of Education and $F$ oreign $A$ ffairs of $J$ apan, other authorities and $M$ embers of the UNU Council.

Until today, the UNU has had five rectors: Dr James Hester (USA) (1975-1980), Soedjatmoko (Indonesia) (19801987), Heitor Gurgulino de Souza (B razil) (1987-1997), Hans V an Ginkel (Netherlands) (1997-2007), and from Switzerland (2007-2013) K onrad Osterwalder. A ppointed in M arch 2013, Dr David M alone (Canada) is the current UNU rector for a 5-year term.

Slowly, over the years, each rector maintained some of the priority areas for the work of UNU, inherited from its predecessors but also introduced changes in the research and training programs of the university, with the approval of the UNU Council. New Research and Training Centers (RTCS) and Programs (RTPS) were progressively set up, with the participation of Scholars and Researchers from all countries around the world, focusing on global problems, looked upon from an interdisciplinary point of view. Y oung researchers, mostly from developing countries, received fellowships from UNU to join the projects and some graduate students have already obtained a M aster and/or Doctor Degree, that UNU has been authorized to grant, by a change in its charter, approved by the UN General A ssembly. So, it can award its own graduate degrees, or do it in partnership with other universities. The global research projects developed are generally financed by UNU, from the annual income of its endowment fund and/or from specific program contributions, donated by other countries, governments, foundations or companies. In recent years, this endowment fund, invested by the UN in New Y ork, has topped US\$350 million dollars (but interest rates, unfortunately, have been coming down) and their decrease affects the overall budgets of the UNU Center and its network of RTCS and RTPS (The biannual UNU budget is around US\$100 million).

Today UNU has 13 RTCS and RTPS in the areas and countries indicated below: UNU-WIDER (World Institute for Development Economics Research), in Helsinki, Finland; the UNU-M ERIT (M aastrichtEconomic and Social Research and Training Center on Innovation and Technology), in the Netherlands; the UNU-IIST (International Institute for Software Technology), in M acau, China; the UNU/INRA (Institute for Natural Resources in Africa), in Ghana; the UNU-IAS (Institute of A dvanced Studies) in Yokohama, Japan; UNU-EHS (Institute for Environment and Human Security) in Bonn, Germany; UNU -CRIS (Institute on Comparative R egional Integration Studies) in Bruges, Belgium; UNU-IIGH (International Institute for Global Health), in K uala L umpur, Malaysia; UNU-INWEH (International Institute for Water, Environment and Health) in Hamilton, Ontario, Canada; UNU -ISP (Institute for Sustainability and Peace) in Tokyo, Japan. UNU also has some important programs: (1) In Caracas, Venezuela (Program for Biotechnology in Latin A merica and the Caribbean); (2) In Ithaca, N ew Y ork, USA (UNU Food and Nutrition Program for Human and Social Development); (3) In Reykjavik, Iceland, UNU has two Programs: UNU Fisheries Training Program and the UNU Geothermal Training Program. Finally, UNU al so has a good network of over 20 associated institutions, designated by the U N U Council, located in China, Thailand, India, K orea, A ustralia, Chile, Germany, M exico, Egypt, USA, Kenya and the UK. Each RTC has its own endowment fund provided by the host country. A nd RTPs have their budgets funded by specific grants from the respective host countries.

The thematic clusters in which UNU has worked during some of the last few years were: (1) peace, security and human rights, (2) human and socioeconomic development and good governance, (3) global health, population and sustainable livelihoods, (4) global change and sustainable development, (5) science, technology, innovation and society.

In these clusters the UNU had, in 2010, over 230 research and study projects, offered 107 training courses (that more than 3.000 students attended) and conducted 212 project workshops. Publications during the year totaled 34 books, 206 articles in peer reviewed journals, 101 chapters of books, 199 working papers and 95 other articles. ${ }^{3}$ 


\section{CONCLUSION}

UNU has acted as a real G lobal Higher Education Institution, since its founding, but it could certainly do much more. In my opinion, some of the main challenges still faced by the UNU are: (1) more financial resources (globally) and for some RTCS and RTPs in developing countries are sorely needed; (2) a smaller and more active council of the UNU and the boards of the RTCs meetings more often is highly desirable; (3) the secretary general should involve the UNU more with the UN Secretariat (in N ew Y ork) and with other UN agencies worldwide.

For further details on the work and current activities of UNU please visit the site: www.unu.edu.

My final remarks on global education, particularly higher education (HE), are from my own country-B razil. As you know, we have a very large country (with a surface area of $8,514,877$ square $\mathrm{km}$, and a population of more than 190 million people today). 0 ur almost 200 universities, 140 university centers and over 2,000 isolated $\mathrm{HE}$ institutions throughout the country, have enrolled close to 7 million students, in 2012, practically double the number we had 10 years earlier. But, in order to even match the numbers of $\mathrm{HE}$ students in Chile and Argentina, not to mention the OECD countries, our HE enrollment should be twice as much as it is today. On the other hand, of the total $\mathrm{HE}$ teaching staff in the country, last year, $69 \%$ already had a doctor' s degree, $26 \%$ a master's degree, $4 \%$ a specialization degree and $2 \%$ had only an undergraduate degree. These numbers were, 10 years earlier, respectively, 51, 33, 10 and $6.5 \%$. So quantity has grown during this decade but qual ity still is lagging behind!

I wish to recall that most of our neighboring countries speak Spanish; B razil is the only country in the region that speaks Portuguese (that we inherited from Portugal). To offer really a 'global education' our HE institutions should have: (1) special curricula; (2) international professors and researchers; (3) foreign students (and should also offer courses in 'lingua franca'-English). Few have a special curricula and very few have international professors and students; very few courses are offered in English in B razil. That is not the case in many other countries. For example, in Tokyo, it was recently launched: 'J apan's abeducationa new push for HE internationalization' ${ }^{4}$ to accelerate the admission of foreign students in J apanese U niversities (goal of 300,000 by 2020), to hire more international professors and offer more courses in English in Japanese $\mathrm{HE}$ institutions.

But in Brazil, despite the great efforts of CAPES (a Foundation attached to the M inistry of Education), that provides fellowships in Brazil and abroad for graduate training for teachers, at the MS, PhD and postdoctoral levels and also due to the continuing efforts of $\mathrm{CN} \mathrm{Pq}$ (attached to the Ministry of Science, Technology and Innovation) devoted mostly to train researchers, at the graduate levelboth agencies have been active during the last 50 years- we are still short of qualified graduates for teaching and research in our growing $\mathrm{HE}$ sector and to work in enterprises (public and private). B etween 2000 and 2008/09, before the global economic crisis appeared, Brazil's economy was growing and continued to growth, although slowly, until recently. Unemployment was relatively low, but there was a recognition that we lacked qualified manpower to continue growing. Estimates have appeared showing we were short of about 150,000 engineers and technicians, of thousands of teachers of mathematics, physics, chemistry, biology and general sciences and even of medical doctors (more than 6,000 , according to the Health M inistry), especially in smaller cities of the countryside.

So the government has launched in 2011, a very ambitious program, entitled 'science without borders' (CSF) aiming to send 101,000 Brazilian students to good universities abroad, for undergraduate, graduate and other special training, between 2011 and 2015, especially in the STEM areas and in all areas of engineering ${ }^{5}$ - (M inistry of Education, B razil-2013).

The government will support 75,000 students (through fellowships given by CAPES and $\mathrm{CNPq}$ ) and the private sector will finance 26,000 students. From the government side: at the level of undergraduate $(27,100$ students will be sent abroad); for doctoral studies-for 1 year $(24,600$ students); for full-time doctor's degree (for 4 years) $(9,790$ students); for postdoctoral studies (1 or 2 years) $(8,900$ students); and there is a plan to attract 390 visiting researchers, to come to B razil (for 3 years). For other modalities of training (even in industries, and in special laboratories, etc.) there are an additional 3,360 fellowships available.

From the private sector side, the Brazilian Federation of $B$ anks will finance 6,500 fellows; the $\mathrm{N}$ ational Confederation of Industries (CNI)-6.000 fellows; Petrobras and the $B$ razilian $A$ ssociation of $B$ asic Industries (A BDIB) 6,000 fellows each. Eletrobras will finance 2,500 fellows and $V$ ale do Rio D oce Company-1,000 fell ows. All fellows will sign an affidavit form stating that, at the end of their studies, they'll return to B razil.

The following countries have al ready received more than 1,000 Brazilian fellows each: USA: 8.378; UK: 5.865; Canada: 4.385; France: 3.909; Portugal: 2979; Spain: 2.901; Germany: 2.812; A ustralia: 2.367; Italy: 2.161; N etherlands: 1.037.

There are also fellows in training in: I reland, Hungary, Korea, B elgium, Norway, Japan, Switzerland, Denmark, 
Finland and other countries, making already a total of 41,133 fellows studying abroad, in 2013.

A problem faced in the implementation of the program has been the lack of knowledge of languages by the potential fellows. To overcome this problem, especially organized language training courses have been set up and are now in place, attended by many thousands potential new fellows.

The expectation of the government is that, when these fellows return to Brazil (at the end of their studies) and, mostly, to their home institutions, they will enrich and improve the quality of the teaching and research staff and help to further globalize HE in the country.

Will this program continue after 2015 ?

Since, Brazil will have presidential elections (in late 2014), either we'll have a continuation of the current government (our constitution allows one re-election) or, a new one will be in office, in 2015. We'll know by then the answer to that question.

Thank you for your attention.

\section{REFERENCES}

1. B oyko H. Science and the future of mankind - W orld A cademy of A rt and Science. The N etherlands: W J unk Publishers; 1961.

2. Charter of the U nited N ations U niversity. General A ssembly of the UN. New Y ork; 1973.

3. U nited Nations University. U NU annual report. Japan: Tokyo; 2011.

4. Kakuchi S. Japan's abeducation - a new push for higher education internationalization. University W orld N ews; 27 J une 2013.

5. Presentation made by the 'M inister of Education of B razil' Senator A loizio M ercadante - Federal Senate, B rasilia; 2013.

\section{ABOUT THE AUTHOR}

\section{Heitor Gurgulino de Souza}

Former Rector, United Nations U niversity, Tokyo, J apan and Former Rector, Federal University, São Carlos, State of São Paulo, B razil

Correspondence Address: SQS 116, B loco B, A pto. 501 B rasilia, DF CEP 70386020-B razil, Phone: +55-6133461414 e-mail: hgurgulino@aol.com 